\title{
FLUIDIZED-BED POTATO WASTE DRYING EXPERIMENTS AT THE RAFT RIVER GEOTHERMAL TEST SITE
}

\author{
Lance T. Cole \\ Richard C. Schmitt
}

Published June 1980

EG\&G Idaho, Inc. Idaho Falls, Idaho 83415

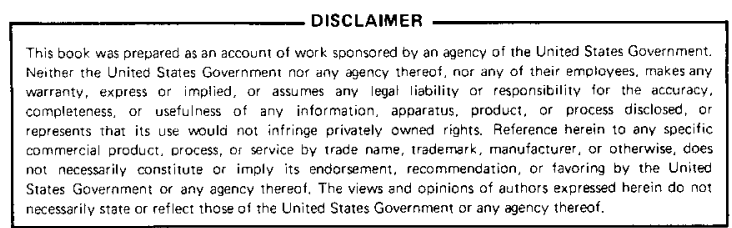

Prepared for the

U.S. Department of Energy Idaho Operations Office

Under DOE Contract No. DE-AC07-76ID01570 


\section{DISCLAIMER}

This report was prepared as an account of work sponsored by an agency of the United States Government. Neither the United States Government nor any agency Thereof, nor any of their employees, makes any warranty, express or implied, or assumes any legal liability or responsibility for the accuracy, completeness, or usefulness of any information, apparatus, product, or process disclosed, or represents that its use would not infringe privately owned rights. Reference herein to any specific commercial product, process, or service by trade name, trademark, manufacturer, or otherwise does not necessarily constitute or imply its endorsement, recommendation, or favoring by the United States Government or any agency thereof. The views and opinions of authors expressed herein do not necessarily state or reflect those of the United States Government or any agency thereof. 


\section{DISCLAIMER}

Portions of this document may be illegible in electronic image products. Images are produced from the best available original document. 


\section{ABSTRACT}

A fluidized-bed dryer was built and operated at the Department of Energy's Raft River Geothermal Test Site in south central Idaho to test the feasibility of using low-temperature $\left(145^{\circ} \mathrm{C}\right.$ or lower) geothermal fluids as an energy source for drying operations. The dryer performed successfully on two potato industry waste products that had a solid content of 5 to $13 \%$. The dried product was removed as a sand-like granular material or as fines with a flour-like texture. Test results, observations, and design recommendations are presented in this report. Also presented is an economic evaluation for commercial-scale drying plants using either geothermal lowtemperature water or oil as a heat source. 


\section{ACKNOWLEDGMENTS}

The authors wish to express their appreciation to the J. R. Simplot Company for their participation in this experimental activity and for making available the potato waste materials for the drying trials. Particular acknowledgment is due to Jim
Oates and Mel Alsager of the Simplot management team for their enthusiasm and support, and to Larry Nisle from the Burley, Idaho processing plant for technical input and arrangements for obtaining the potato waste material. 


\section{CONTENTS}

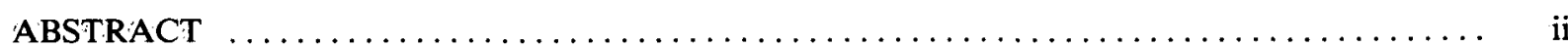

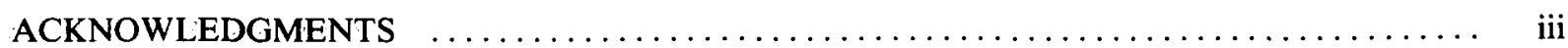

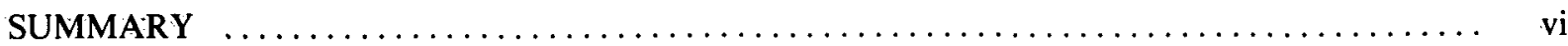

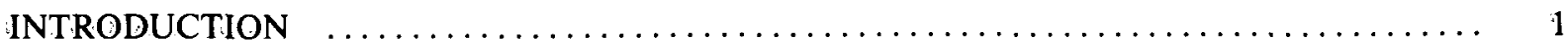

EXPERIMENTAL $\ldots \ldots \ldots \ldots \ldots \ldots \ldots \ldots \ldots \ldots \ldots \ldots \ldots \ldots \ldots \ldots \ldots \ldots \ldots \ldots \ldots \ldots \ldots \ldots \ldots, 2$

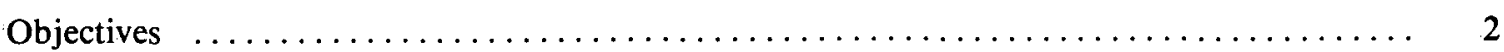

Experiment Description $\ldots \ldots \ldots \ldots \ldots \ldots \ldots \ldots \ldots \ldots \ldots \ldots \ldots \ldots \ldots \ldots \ldots \ldots \ldots, 2$

Equipment $\ldots \ldots \ldots \ldots \ldots \ldots \ldots \ldots \ldots \ldots \ldots \ldots \ldots \ldots \ldots \ldots \ldots \ldots \ldots \ldots \ldots \ldots \ldots \ldots \ldots, 2$

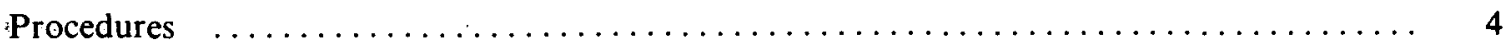

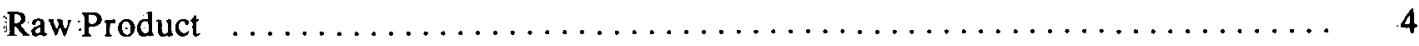

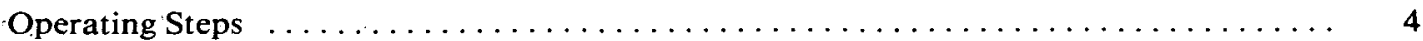

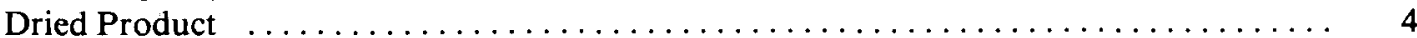

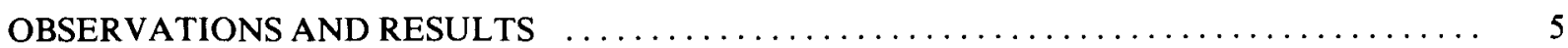

Control Measures and Operating Parameters $\ldots \ldots \ldots \ldots \ldots \ldots \ldots \ldots \ldots \ldots \ldots \ldots \ldots \ldots \ldots$

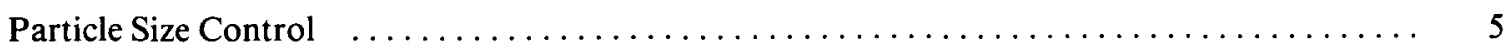

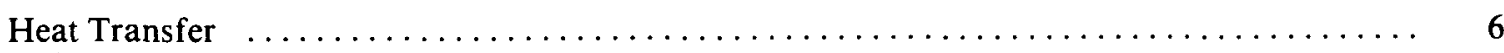

Steam as an Atomizing Medium $\quad \ldots \ldots \ldots \ldots \ldots \ldots \ldots \ldots \ldots \ldots \ldots \ldots \ldots \ldots \ldots \ldots \ldots \ldots$

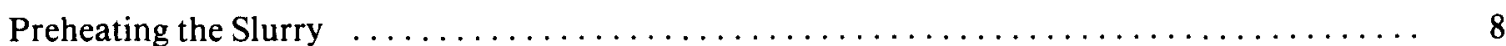

Preheating the Fluidizing Air $\quad \ldots \ldots \ldots \ldots \ldots \ldots \ldots \ldots \ldots \ldots \ldots \ldots \ldots \ldots \ldots \ldots, \quad 8$

Comparative Analyses of Dried Product $\ldots \ldots \ldots \ldots \ldots \ldots \ldots \ldots \ldots \ldots \ldots \ldots \ldots \ldots \ldots \ldots \ldots$

SCALE-UP DESIGN RECOMMENDATIONS AND ECONOMICS $\ldots \ldots \ldots \ldots \ldots \ldots \ldots \ldots \ldots$

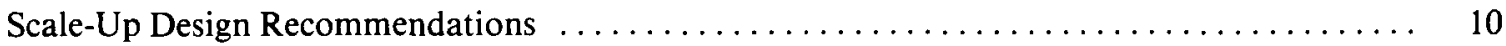

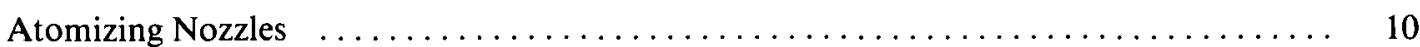

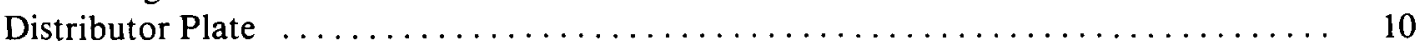

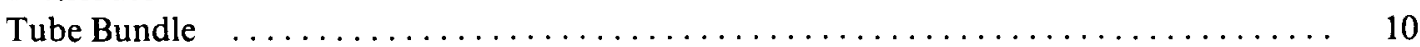

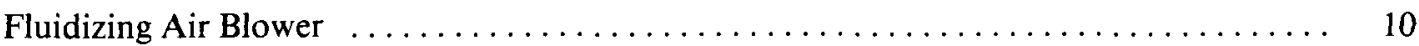

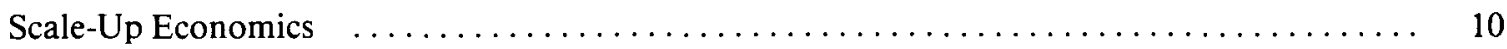

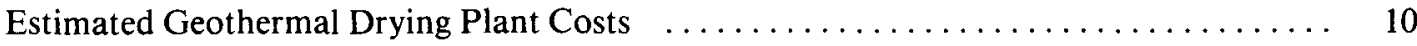

Comparative Economic Analysis of Geothermal- and Oil-Using Drying Plants . . . . . $\quad 11$ 


\section{FIGURES}

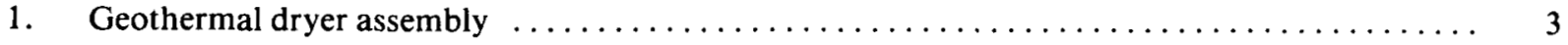

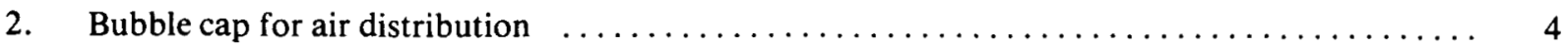

3. Bed-side heat transfer as a function of fluidizing air velocity $\ldots \ldots \ldots \ldots$

\section{TABLES}

1. Potato Waste Bioanalyses $\ldots \ldots \ldots \ldots \ldots \ldots \ldots \ldots \ldots \ldots \ldots \ldots \ldots \ldots \ldots \ldots \ldots \ldots$

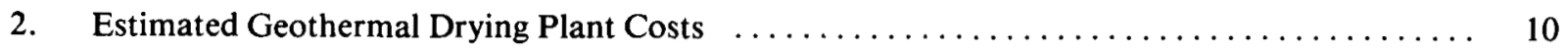

3. Comparative Costs of Geothermal- and Oil-Using Drying Plants $\ldots \ldots \ldots 11$

4. Comparative Economic Analysis of Geothermal- and Oil-Using Drying Plants $\ldots \ldots \ldots 12$ 


\section{SUMMARY}

This report describes an experiment performed to demonstrate the feasibility of using lowtemperature $\left(145^{\circ} \mathrm{C}\right.$ or lower $)$ geothermal water as a heat source to dry slurry-like materials using fluidized bed dryers. The dryer designed for this experiment used a gas-fluidized bed heated by a tube bundle, through which geothermal fluid circulated. The material to be dried, waste material from the potato processing industry, was sprayed through an atomizing nozzle into the bed surrounding the tube bundle. Overall heat transfer coefficients of 130 to $160 \mathrm{~W} / \mathrm{m}^{2} \cdot \mathrm{K}$ were experimentally determined for the tube bundle.

The most critical aspect of the drying process was efficient atomization of the slurry. When good atomization was achieved, the drying process was trouble-free, and the dried product had a uniform consistency. Thermocouples located throughout the bed supplied information necessary for preventing and locating operational problems.

An economic evaluation was performed for two kinds of scaled-up, commercial-size drying plants; one using geothermal water and the other using oil as a heat source. The evaluation indicated a relatively short payback period for a 6-MW(t) drying plant producing a dried product valued at $\$ 200$ to $\$ 500$ per ton.

Although more work is needed on scaled-up atomizing nozzles, the dryer used in this study. demonstrated that low-temperature geothermal fluids can successfully dry industrial products. This energy resource is available to many industries, and merits developmental consideration for drying applications. 


\section{FLUIDIZED-BED POTATO WASTE DRYING EXPERIMENTS AT THE RAFT RIVER GEOTHERMAL TEST SITE}

\section{INTRODUCTION}

Geothermal hot water is available in many locations throughout the world. In many areas, this water temperature is relatively low $\left(145^{\circ} \mathrm{C}\right.$ or less) and has marginal economics for generating electricity; however, the direct use of geothermal energy in nonelectric applications has excellent potential for replacing valuable fossil fuels. EG\&G Idaho, Inc., has pursued some of these direct applications at the Department of Energy's Raft River Geothermal Test Site in south central Idaho.

One such application is in process drying. Some process industries have waste products that are of considerable value for animal-feed protein or for fertilizer. These waste products must be dried, however, to have a significant storage life, and to reduce weight and volume for transportation. This need prompted the development of an experimental dryer based on the gas-fluidized bed principle and using geothermal energy as the heat source.

In this experiment, two kinds of waste materials from the potato processing industry were successfully dried. The potato waste was provided by the J.R. Simplot Company, a large potato processing firm in Idaho and a participant in this experiment. The successful operation of the experimental dryer, which dried the slurry-like waste material, shows the potential for drying many liquid-form industrial products. The system could also be modified to dry solid products such as grain, beet pulp, onions, and other vegetable products.

In gas-fluidized beds, a gas, in this case air, passes upward through a bed of solid particles. When the air velocity reaches a point where drag forces exceed particle weight, the particles begin to vibrate and move about - a condition called incipient fluidization, or minimum fluidization. Increasing the air flow rate causes large instabilities, bubbling, and channeling of the gas. At higher flow rates, agitation becomes more violent and the particles move more vigorously. This agitated movement enhances heat transfer rates from surfaces exposed to the fluidized bed. Also, the bed becomes isothermal because of the intense mixing action. These properties of a gas-fluidized bed are used in conjunction with a heat exchange tube bundle to transfer heat from geothermal water to the material being dried, which is sprayed by an atomizing nozzle into the bed.

The gas-fluidized bed dryer used in this experiment is one of many possible designs ${ }^{1}$ and is not proposed as the only acceptable process. The gasfluidized bed dryer concept does, however, show excellent promise for industrial drying needs. 


\section{EXPERIMENTAL}

\section{Objectives}

The objectives of this experiment were:

1. To show the feasibility of using low- to moderate-temperature geothermal heat to dry slurry-like materials, and

2. To determine dryer design parameters such as heat transfer coefficients, fluidizing air velocities, and nozzle air-to-liquid volume ratios to aid in the design of a pilot scale or larger dryer assembly.

\section{Experiment Description}

The dryer developed for this experiment (Figure 1) used the gas-fluidized bed principle. ${ }^{2}$ Geothermal water was circulated on the tube side of the heat exchanger bundle, and an air column fluidized a bed of dried material around the tubes in the heat exchanger. The fluidized bed allowed excellent heat transfer and mixing, and provided a hot, isothermal bed that dried slurry materials sprayed in an atomized mist into the bed. The atomized material dried almost instantly upon contact with the bed, and the dried product was removed by a simple gravity-fed overflow tube. The heated air, steam, and dust-like fines exited the dryer through the top of the vessel and were routed to a cyclone separator to remove the fines before venting to atmosphere.

\section{Equipment:}

The equipment used for this experiment is described below:

- Vessel. The dryer vessel (Figure 1) was about $2.4 \mathrm{~m}(8 \mathrm{ft})$ tall, including all connections, and was basically a vertical section of 250 by $250 \mathrm{~mm}$ rectangular structural tubing with a distributor plate at its bottom end to distribute fluidizing air to the bed material. The tubing wall was adapted to accept two heat exchange bundles, and was tapped to allow the installation of the atomizing nozzle. A $51-\mathrm{mm}$ pipe, installed at the top of the vessel, allowed removal of fluidizing air and moisture removed during the drying process. The dryer assembly was supported by an angle iron stand (not shown in the figure).

- Distributor Plate. Located at the bottom of the vessel with an air plenum below, the 9-mm-thick distributor plate was tapped in 24 places to accept bubble cap-type air distributors (Figure 2). A 28-mm disc was brazed to the top of each cap and the other end was threaded to allow attachment to the plate. Four $5.5-\mathrm{mm}$ holes were drilled through the cap wall beneath the disc to admit fluidizing air. This design prevented bed material from falling into the plenum when air flow was stopped, and allowed easy replacement and modification of the caps.

- Blower. A Model 2LB Sutorbilt Rotary Blower, driven by a 1-hp variable-speed motor, supplied air to the plenum.

- Atomizing Nozzle. A Model 1/4-J: External Mix Spraying Systems nozzle, supplied with air by a compressor, atomized the slurry, which was pumped to the nozzle by a Model 3M2 Moyno progressing cavity pump.

- Tube Bundle. Each tube bundle, with $1.2 \mathrm{~m}^{2}\left(13.7 \mathrm{ft}^{2}\right)$ of surface area, was: a four-pass $U$-tube of $9-\mathrm{mm}$, 20-gauge: stainless steel rolled into a $19-\mathrm{mm}$ tube sheet with a triangular pitch-to-tubediameter ratio of 1.5 . Only one bundle was: in place during this experiment.

- Cyclone. Installed in the vessel's exit pipe, the cyclone removed fines entrained in the air stream.

- Colloid Mill. A 100-mm Premier Colloid Mill with a $0.025-\mathrm{mm}$ rotor-stator gap: ground up too-large slurry particles to prevent clogging the atomizing nozzle orifice.

In addition, thermocouples were located throughout the bed to monitor operating 


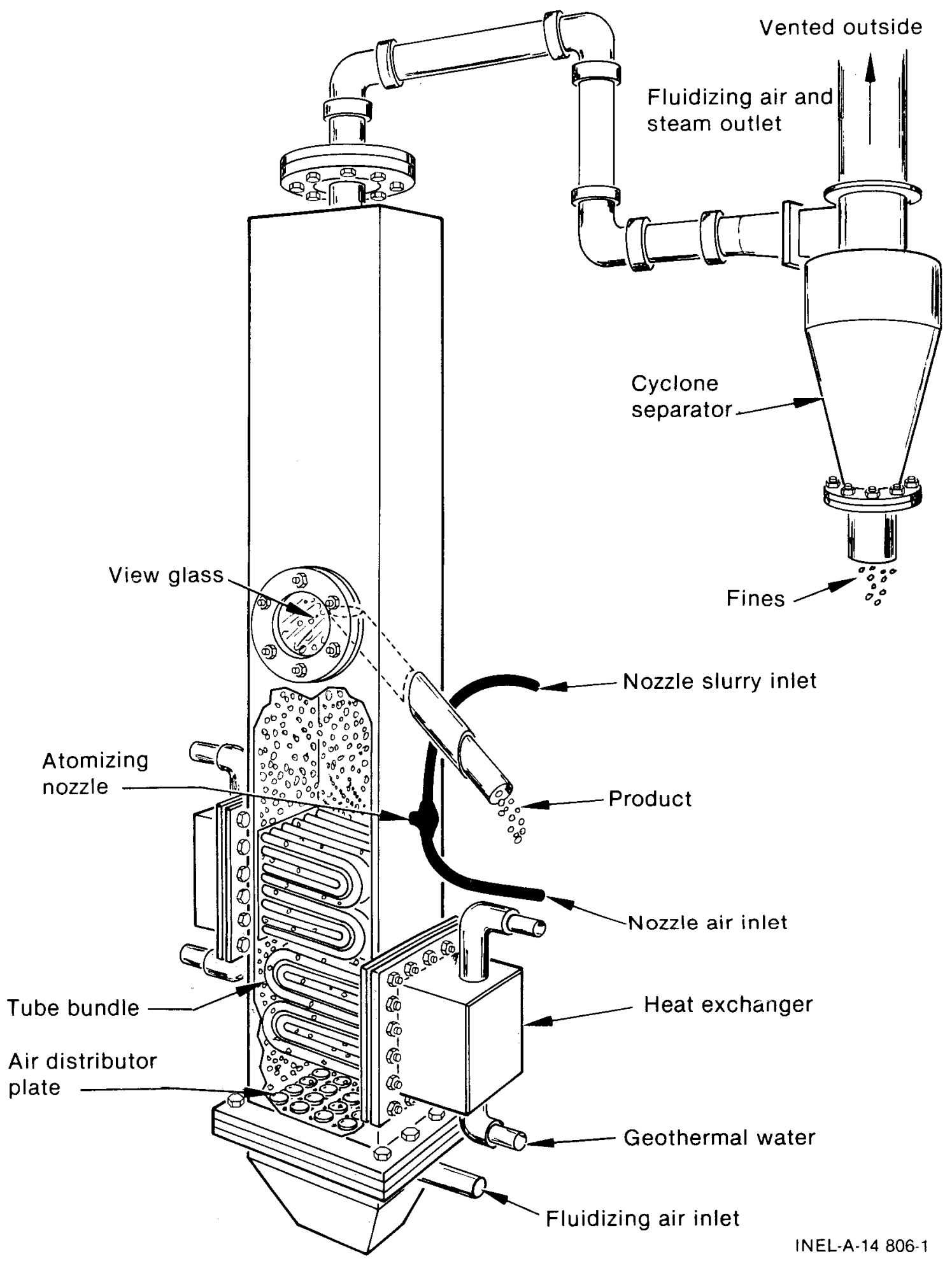

Figure 1. Geothermal dryer assembly. 


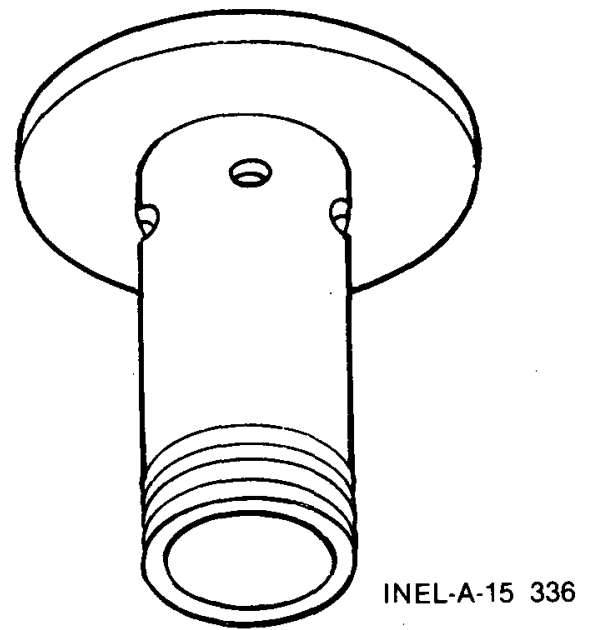

Figure 2. Bubble cap for air distribution.

temperatures, and a drain tube at the bottom of the bed allowed complete removal of bed material.

\section{Procedures}

Raw Product. Most of these initial drying tests were performed with "dry-peel" potato waste, which is a common waste product of potato processors. Potatoes are first dipped into a caustic solution to loosen the peels. Then a rolling drum removes the loosened peels. The dry-peel material used in these tests had a bulk density of $0.9 \mathrm{~g} / \mathrm{cc}$ and was about $13 \%$ solids. The slurry's viscosity was $42,000 \mathrm{cp}$ at room temperature.

A second potato waste product, an activated biomass material, was also dried. This material results from secondary waste treatment, and consists of bacteriological single-cell protein. The biomass is 50 to $60 \%$ protein as compared to grass, which is 10 to $15 \%$ protein. Before being dried, the biomass material was concentrated at the potato processing plant by large centrifuges from its initial $0.5 \%$ solids content to 5 to $8 \%$ solids content. The slurry then had the consistency of chocolate pudding, a bulk density of $1.0 \mathrm{~g} / \mathrm{cc}$, and a viscosity of $80,000 \mathrm{cp}$ at room temperature.

Operating Steps. The drying experiment proceeded as follows:

1. The slurry was preconditioned by passing it through the colloid mill with its rotorstator gap set at $0.025 \mathrm{~mm}$. This was necessary to prevent clogging the atomizing nozzle with too-large particles.

2. The rotary blower was turned on to supply fluidizing air to the vessel plenum, and the motor speed was adjusted to achieve optimum bed fluidization.

3. Heat was added to the fluidized bed by opening the valve to circulate hot geothermal water through the tube side of the heat exchanger bundle. Water temperature was about $130^{\circ} \mathrm{C}$.

4. The air compressor was turned on to supply air to the atomizing nozzle, and the bed was allowed to reach steady-state temperature.

5. The cavity pump was turned on to supply slurry to the atomizing nozzle and begin the drying operation. Slurry flow was adjusted to bring the isothermal bed temperature to the desired running temperature.

Water in the atomized slurry vaporized almost instantly upon contact with the heated bed particles, and the suspended bed level rose as material was added and dried. Dried solids were pulled by gravity through the overflow tube into a container that had a positive pressure to prevent moist air from contacting the dried product. The cyclone removed fines from the air stream exiting the dryer vessel.

Dried Product. Since drying temperatures were in the superheat region, the dried product contained $0.2 \%$ or less unbound moisture. The product was hydroscopic, however, and could absorb water after being dried. This characteristic might be desirable for feeding operations.

When the equipment was operated under design conditions, the dry-peel product was granular with a typical mean particle diameter of $0.4 \mathrm{~mm}$ and a bulk density of $1.2 \mathrm{~g} / \mathrm{cc}$. Fines removed by the cyclone were flour-like in consistency. The ratio of fines to granular product was dependent on operating conditions such as fluidizing air velocity and atomizing nozzle air pressure.

The dried biomass product was considerably different from the dry-peel product. It was much more fragile and more easily broken into tiny particles. 


\section{OBSERVATIONS AND RESULTS}

The gas-fluidized bed dryer will dry any material in slurry form that can be pumped through the atomizing nozzle without clogging and that can be dispersed in an atomized mist by the nozzle air stream. Many materials may need to be uniformly sized by a colloid mill, such as was used in this experiment, or by an in-line grinder for larger scale operations.

The drying process in a fluidized bed requires an initial seed bed. There are many candidates for this starter bed such as grass seed, potato granules, and even nonorganic materials such as sand. The main constraint is that the material must fluidize in the velocity range available. The initial choice of bed material is not critical, since the bed will be diluted according to the formula: ${ }^{3}$

$\mathrm{X}=1-\mathrm{e}^{-\mathrm{Pt} / \mathrm{W}}$

where

$$
\begin{aligned}
& \mathrm{X}=\quad \begin{array}{l}
\text { weight fraction of initial bed material } \\
\text { removed }
\end{array} \\
& \mathbf{W}=\quad \text { weight of bed, } \mathrm{kg} \\
& \mathrm{P}=\text { product rate, } \mathrm{kg} / \mathrm{hr} \\
& \mathrm{t}=\text { time, hours. }
\end{aligned}
$$

According to this formula, $90 \%$ of the initial bed will be removed after 100 to 300 hours of operation for typical design configurations. The dilution is a result of the random removal of the initial bed particles through the product takeoff tube. If the dried material is to be used for animal food, it may be advantageous to start with an edible bed material to eliminate the need to dispose of the initial product.

\section{Control Measures and Operating Parameters}

As the slurry is introduced to the heated bed, the bed temperatures drop at a rate determined by the rate of slurry input. During this experiment, particle agglomeration occurred when the isothermal bed temperatures dropped below $105^{\circ} \mathrm{C}$. This showed that a superheat of $15^{\circ} \mathrm{C}$ is needed to avoid bed agglomeration.

The gas-fluidized bed operates isothermally as long as the bed is homogeneous; temperatures at any point in the fluidized bed are within $3^{\circ} \mathrm{C}$ if the bed is fluidizing uniformly. Nonuniform bed fluidization can be easily detected by the deviation of any of the bed thermocouple temperatures from the normal operating temperature.

During testing, the temperature of the bed near the distributor sometimes fell as much as $50^{\circ} \mathrm{C}$ below the rest of the bed. This resulted from particle agglomeration, causing the heavier and larger particles to settle to the bottom of the bed, unable to fluidize in the air stream. In this stagnant condition, there is little heat transfer or mixing, causing the bottom of the bed to be much cooler than the upper regions.

A bed clog is indicated when one of the upperregion temperatures decreases substantially. This decrease occurs because the clogging stops bed mixing, causing the clogged area to cool. A clog always begins near the nozzle, the source of the undried material.

\section{Particle Size Control}

The quality of atomization achieved by the atomizing nozzle is the key to controlling particle size and agglomeration. The choice of nozzle will be dictated by the slurry properties. The nozzle orifice must be large enough to avoid partial or complete clogging due to any nonhomogeneous properties of the slurry. An orifice size of $2.0 \mathrm{~mm}$ is necessary to avoid clogging the nozzle with the dry-peel slurry. The high viscosity and cohesive nature of the dry-peel slurry requires a nozzle airto-liquid volume ratio (NAR) of 1800 to 2500 , with the air volume measured at standard conditions, to achieve good atomization. Lower ratios result in agglomeration of the particles due to poor atomization of the slurry.

The biomass material atomized well with an orifice size of $2.0 \mathrm{~mm}$ and requires NARs of 800 to 1200 to achieve good atomization. This 
material does not agglomerate as easily as the drypeel mixture.

When the slurry is sprayed into the heated fluidized bed, it is dried by coating seed particles present in the fluidized bed (see Reference 3 ). The particles develop in layers much as a tree grows 4 and new seed particles are formed due to attrition of larger bed particles. Ideally, the drying process is performed by each individual particle, but sometimes, under improper operating conditions, the particles stick together, or agglomerate in clusters similar to the cereal "Grape Nuts." Under very unfavorable conditions, clusters can be even larger. Large deviations from proper operating conditions result in a clog of the bed, necessitating dryer shutdown and cleaning.

Two methods may be used to break up the unwanted larger particles:

1. Place a screen of fine wire with 6-mm or smaller squares just above the tube bundle. This breaks up the particles as they strike the wire; or

2. Place an air jet in the bottom to grind up the particles. A target can be used for particle breakup by impact. This method produces many fines, which may be undesirable. It is possible to produce so many fines that the bed height decreases enough to uncover the nozzle spray and cause a clog.

\section{Heat Transfer}

Heat is transferred from the geothermal water on the tube side of the heat exchanger to the tube wall. The heat is then transferred from the tube wall to the fluidized bed material and the fluidizing air. The bed-side heat transfer coefficient was determined experimentally by performing a heat balance on the exchanger using the following standard relationships: ${ }^{5}$

$$
\begin{aligned}
& \mathrm{q}=\dot{\mathrm{m}} \mathrm{C}_{\mathrm{p}}\left(\mathrm{T}_{\text {in }}-\mathrm{T}_{\text {out }}\right) \\
& \mathrm{q}=\mathrm{U}_{\mathrm{o}} \mathrm{A} \Delta \mathrm{T} \\
& 1 / \mathrm{h}_{\mathrm{o}}=1 / \mathrm{U}_{\mathrm{o}}-\mathrm{r}_{\mathrm{o}}\left(\frac{}{\mathrm{r}_{\mathrm{i}} \mathrm{h}_{\mathrm{i}}}+\frac{\ln \left(\mathrm{r}_{\mathrm{o}} / \mathrm{r}_{\mathrm{i}}\right)}{\mathrm{k}}\right)
\end{aligned}
$$

where

$$
\begin{aligned}
& \mathrm{q}=\text { rate of heat transfer }(\mathrm{cal} / \mathrm{s}) \\
& \dot{\mathrm{m}}=\text { geothermal water mass flow rate } \\
& (\mathrm{kg} / \mathrm{s}) \\
& \mathrm{C}_{\mathrm{p}}=\text { specific heat of fluid }(\mathrm{cal} / \mathrm{g} \cdot \mathrm{C}) \\
& \mathrm{T}_{\text {in }}=\text { geothermal water inlet temperature } \\
& \text { (K) } \\
& \mathrm{T}_{\text {out }}=\begin{array}{l}
\text { geothermal } \text { water outlet tempera- } \\
\text { ture (K) }
\end{array} \\
& U_{0}=\text { overall heat transfer coefficient } \\
& \left(\mathrm{W} / \mathrm{cm}^{2} \cdot \mathrm{K}\right) \\
& \text { A }=\text { tube-side heat exchange area }\left(\mathrm{m}^{2}\right) \\
& \Delta \mathrm{T}=\log \text { mean temperature difference (K) } \\
& h_{\mathrm{o}}=\text { shell-side heat transfer coefficient } \\
& \left(\mathrm{W} / \mathrm{cm}^{2} \cdot \mathrm{K}\right) \\
& r_{0}=\text { heat exchanger tube outside radius } \\
& \text { (cm) } \\
& r_{i}=\text { heat exchanger tube inside radius } \\
& \text { (cm) } \\
& \mathrm{h}_{\mathrm{i}}=\text { tube-side heat transfer coefficient } \\
& \left(\mathrm{W} / \mathrm{cm}^{2} \cdot \mathrm{K}\right)
\end{aligned}
$$

The bed-side (shell-side) heat transfer coefficient $\left(\mathrm{h}_{\mathrm{o}}\right)$ represents $90 \%$ or more of the total resistance to heat transfer from the geothermal water to the fluidized bed. The heat transfer coefficient existing at the tube surface and bed interface was found to be a strong function of superficial fluidizing air velocity as shown in Figure 3. Superficial velocity is defined as the velocity of the air through the vessel with no tube bundle present. The test results, using a dry-peel bed, show maximum bed-side heat transfer coefficients of approximately $165 \mathrm{~W} / \mathrm{m}^{2} \cdot \mathrm{K}$ occurring at air velocities of 60 to $70 \mathrm{~cm} / \mathrm{s}$, for a mean particle diameter of $0.4 \mathrm{~mm}$. 


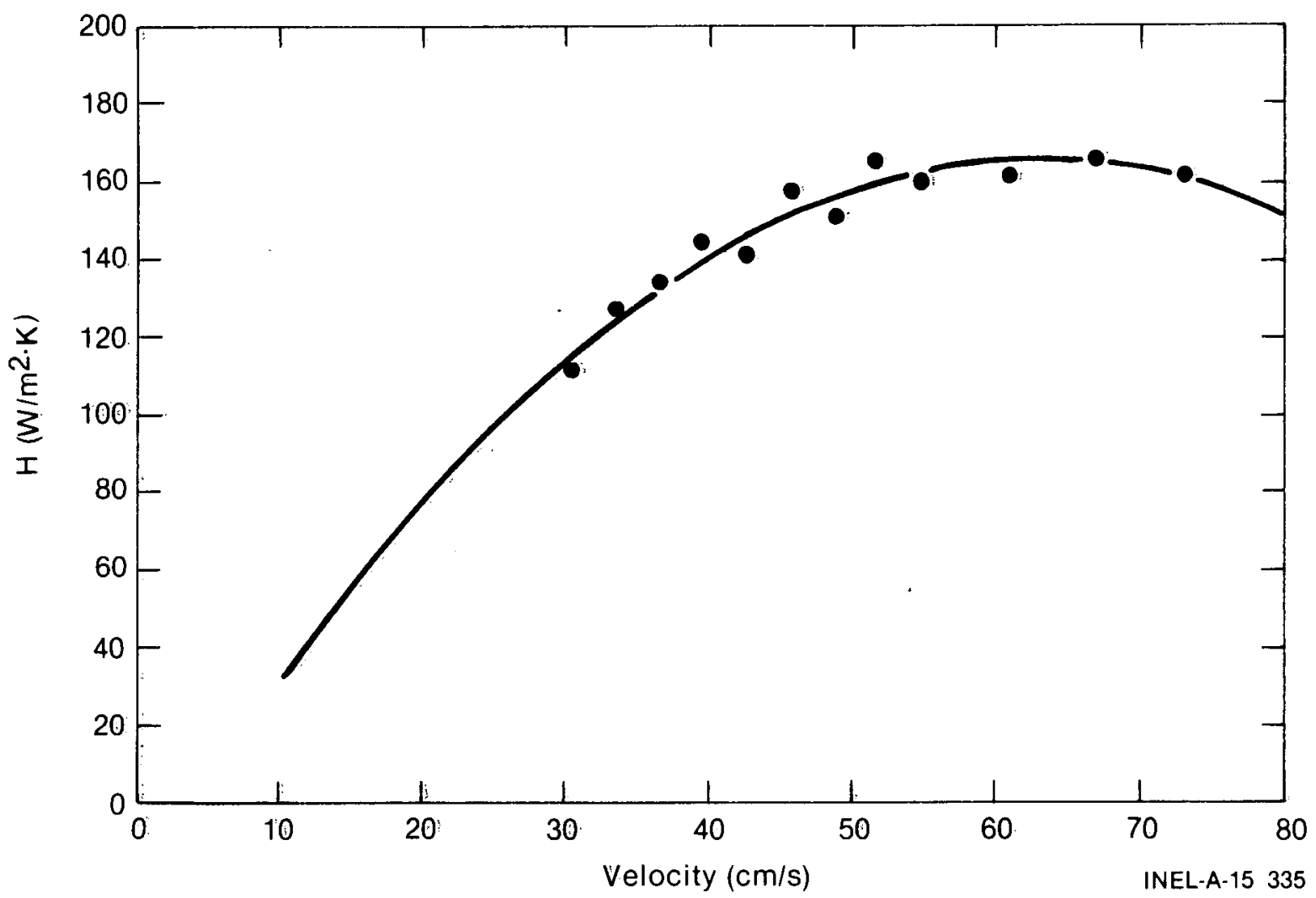

Figure 3. Bed-side heat transfer as a function of fluidizing air velocity.

Heat transfer coefficients of the same magnitude as those obtained with the dry-peel were observed with the biomass. Correlations by other experimenters for tube surface heat transfer coefficients: show a dependence on particle diameter and material properties. These correlations for heat transfer coefficients at the surface of tubes submerged in fluidized beds exhibit a wide divergence between different correlations; , and between correlations and experimental data:. The state-of art has an uncertainty band on the order of' $100 \%$. The article by Chen 7 has an extensive list of references: for any reader desiring: more information on past experimentall correlations.

Gas-fluidized bedsi exhibit aggregate fluidization where gas bubbling and channeling are present. The bed does not expand much beyond its: original volume at minimum fluidization.8 The: occurrence of a maximum heat transfer capacity in this dryer may be due to the fact that the gas bubbles enlarge as the velocity is increased, causing less bed to be in contact with the tubes at any time. Also, the flow separation from the tubes: may increase as the flow velocity increases, since the flow is still within the laminar region.
The fluidizing air velocity at which the maximum heat transfer coefficient occurs is not usually the most efficient velocity for drying. A considerable amount of sensible heat is absorbed by the fluidizing air, detracting from the heat available to evaporate the moisture in the raw product. The most efficient fluidizing air velocity can be determined mathematically. The energy available for drying $\left(\mathrm{q}_{\mathrm{d}}\right)$ is expressed by:

$\mathrm{q}_{\mathrm{d}}=\mathrm{U}_{\mathrm{o}} \mathrm{A} \Delta \mathrm{T}-\dot{\mathrm{m}}_{\mathrm{a}} \mathrm{C}_{\mathrm{p}}\left(\mathrm{T}_{2}-\mathrm{T}_{1}\right)$

where

$$
\begin{aligned}
& \mathrm{qd}_{\mathrm{d}}=\begin{array}{l}
\text { energy: available for actual product } \\
\text { drying (cal/s) }
\end{array} \\
& \mathrm{U}_{\mathrm{O}}=\begin{array}{l}
\text { overall heat transfer coefficient } \\
\left(\mathrm{W} / \mathrm{cm}^{2} \cdot \mathrm{K}\right)
\end{array} \\
& \mathrm{A}=\quad \text { tube-side heat exchange arear }\left(\mathrm{m}^{2}\right) \\
& \Delta \mathrm{T}=\quad \text { log mean temperature difference }(\mathrm{K}) \\
& \dot{\mathrm{m}}_{\mathrm{a}}=\text { fluidizing air mass flow rate }(\mathrm{kg} / \mathrm{s})
\end{aligned}
$$


$C_{p}=$ specific heat of fluid $(\mathrm{cal} / \mathrm{g} \cdot \mathrm{C})$

$T_{2}=$ exiting fluidizing air temperature

$\mathrm{T}_{1}=$ entering fluidizing air temperature.

Differentiating Equation (5) with respect to fluidizing air velocity $(\mathrm{V})$ yields:

$$
\frac{\mathrm{dq}_{\mathrm{d}}}{\mathrm{dV}}=\mathrm{A} \Delta \mathrm{T} \frac{\mathrm{dU}_{\mathrm{O}}}{\mathrm{dV}}-\mathrm{C}_{\mathrm{p}}\left(\mathrm{T}_{2}-\mathrm{T}_{1}\right) \frac{\mathrm{dm}}{\mathrm{dV}}
$$

where

$\mathrm{V}=$ fluidizing air velocity $(\mathrm{cm} / \mathrm{s})$.

Setting Equation (6) to equal zero, and solving for $\mathrm{V}$ will give the most efficient fluidizing air velocity. Solving these equations indicates that for the dryer used in this experiment with one tube bundle present, optimum performance occurs at a fluidizing air velocity of $48.8 \mathrm{~cm} / \mathrm{s}$.

Careful design of the tube bundle could result in decreased heat exchanger area requirements. Evidence of the importance of tube bundle design is found in Reference 3, where one tube bundle gave heat transfer coefficients of 45 to $280 \mathrm{~W} / \mathrm{m}^{2} \cdot \mathrm{K}$, while another bundle gave coefficients of 225 to $565 \mathrm{~W} / \mathrm{m}^{2} \cdot \mathrm{K}$. Reference 9 reports experimentation which shows that vertically oriented heat exchange tubes give better heat transfer coefficients than horizontally oriented tubes. Also, finned tubes may reduce tube bundle volume requirements. Reference 7 reports experimentation showing maximum duty per unit bed volume can be increased up to $300 \%$ by use of finned tubes.

Studies of tube bundle design could prove valuable, since improvement of the heat transfer capabilities of a bundle decreases not only the initial equipment costs, but also the parasitic costs of supplying and heating unneeded fluidizing air. Greater tube bundle efficiencies would allow a physically smaller dryer to be built, which would require less air for fluidizing the bed.

\section{Steam as an Atomizing Medium}

A steam flasher was set up to provide steam from geothermal hot water to the atomizing nozzle. Due to the relatively low geothermal temperatures, the maximum steam pressure available was
35 psi $(241 \mathrm{kPa})$. Steam did not perform acceptably as an atomizing medium; particles in the bed started to agglomerate after short periods of operation. Superheating the steam to prevent condensation did not eliminate the problem.

Visual observation of the nozzle in operation while removed from the dryer, with steam as the atomizing medium, showed rapid pulsing of the exiting slurry. This was caused by superheating and flashing of the slurry in the nozzle due to heat taken from the steam through the nozzle wall. This indicates that a radically different nozzle design is needed if steam is to be used for atomizing. Also, higher steam pressures may be necessary for good atomization. These pressures are not available from flashed $130^{\circ} \mathrm{C}$ geothermal water.

\section{Preheating the Slurry}

Preheating the slurry to temperatures below superheat can improve the dryer's output by up to $11 \%$, primarily because of the slurry's energy gain. Superheating the slurry, however, results in bed clogging. Observation of the nozzle in operation outside of the dryer revealed that slugging takes place in the slurry line when the slurry is superheated. Intermittent bursts of steam and slurry from the nozzle, caused by superheating, eventually resuits in a bed clog.

\section{Preheating the Fluidizing Air}

Heating the fluidizing air represents a significant part of the energy that would otherwise be available to vaporize the liquid content of the slurry. Preheating the air would increase the capacity of this dryer by $3 \%$ for each $5.5^{\circ} \mathrm{C}$ that the air is preheated, with one heat exchange tube bundle in place. The percentage increase would be half as much when two tube bundles are in place. This sizable energy drain associated with heating fluidizing air shows the importance of minimizing the fluidizing air needed.

\section{Comparative Analyses of Dried Product}

AGRI-TEST, Inc., an agricultural testing laboratory in Twin Falls, Idaho, analyzed the potato waste slurry and the dried product from the fluidized bed dryer. Results are shown in Table 1. 
Table 1. Potato waste bioanalyses

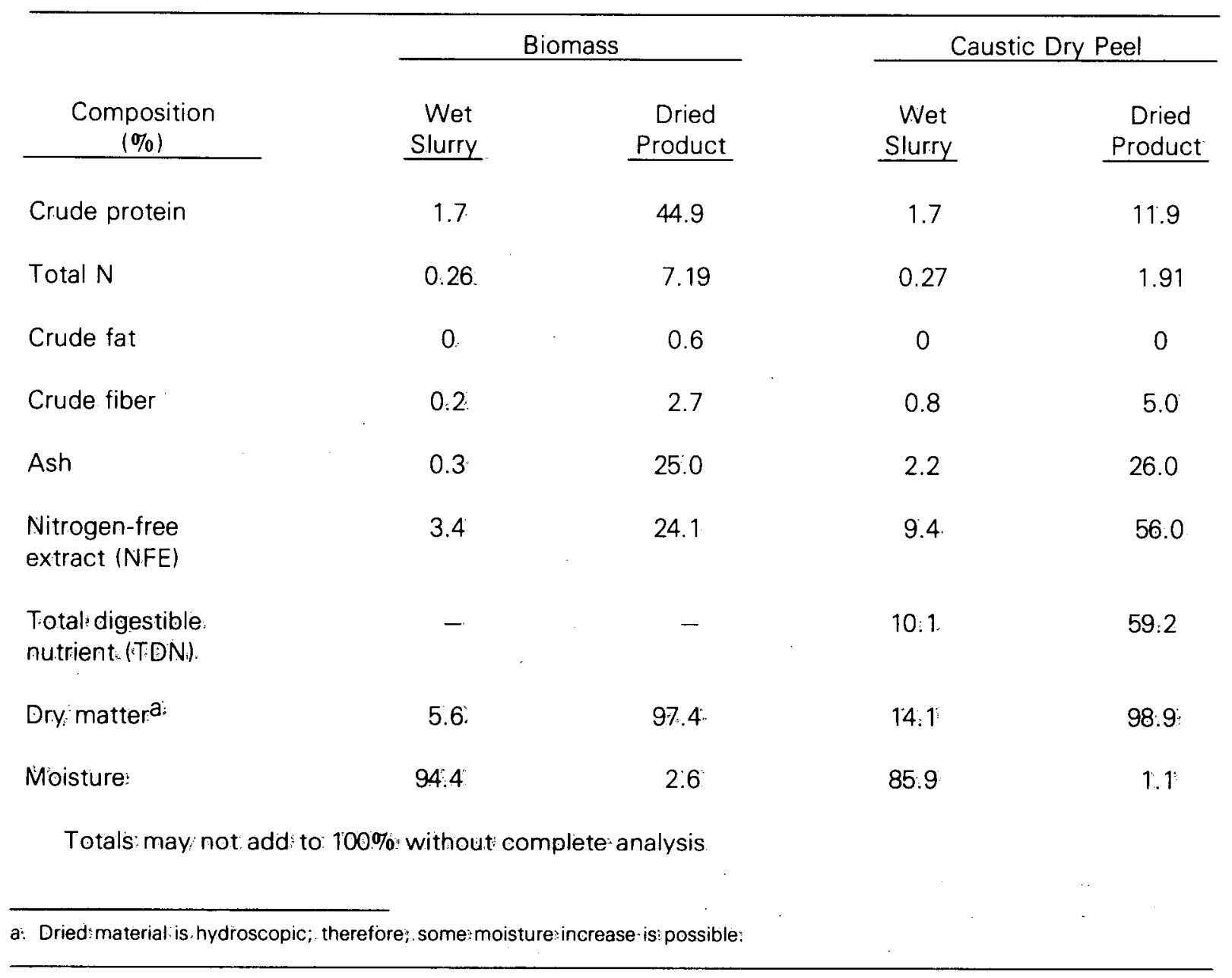




\section{SCALE-UP DESIGN RECOMMENDATIONS AND ECONOMICS}

\section{Scale-Up Design \\ Recommendations}

Atomizing Nozzles. Nozzle choice and design are critical in the design of larger dryers to maintain a granular, uniform product. It will be necessary to conduct tests on larger nozzles to determine the effect of larger capacities on the atomization of viscous slurries. The nozzle air-toliquid volume ratios needed for the small atomizing nozzle used in this experiment may apply in the larger nozzle, but confirming tests are needed. The atomizing nozzles chosen should not have protruding parts, which attract buildup that might cause clogging.

Distributor Plate. The design of the distributor plate also is critical in larger vessels. The pressure drop across the plate should be at least $30 \%$ of the drop across the bed. This will force air through the distributor in all places, not allowing the bed to collapse and stagnate in any area.

Tube Bundle. A good tube bundle design can significantly reduce the size of the dryer. This will reduce initial capital cost of the tube bundle and require less fluidizing air. The requirement for less fluidizing air is beneficial in two ways: (a) a smaller blower can be used which requires less power to operate and less initial cash outlay; and (b) less heat will be used to heat fluidizing air, freeing the energy for drying the product. The use of a well-designed finned tube heat exchanger bundle, as discussed in the Heat Transfer section of this report, will contribute to an efficient, compact heat exchanger.

Further, the tube bundle should be designed to give the minimum practical cross sectional flow area to the fluidizing air. This constraint will lead to a relatively narrow, deep bed with a compact tube bundle design.

Fluidizing Air Blower. The blower used to supply the fluidizing air might better be used to pull, rather than push, the air through the dryer. This would reduce the pressure in the bed, lowering the boiling temperature of the water in the slurry, which would increase the capacity of the dryer. For every degree $C$ that the boiling point of water is decreased, the capacity of the dryer increases $4 \%$. Reduction of the operating pressure by 2 psi $(13.8 \mathrm{kPa})$ will increase the dryer capacity by $18 \%$. Therefore, it may be advantageous to design a large pressure drop through the distributor plate and pull the air with a blower to reduce the operating pressure.

\section{Scale-Up Economics}

Estimated Geothermal Drying Plant Costs. A typical waste drying plant might be required to produce 25 dry tons per 24 hours, operating 250 days per year. A plant this size would require $6 \mathrm{MW}$ of heat to dry the product, assuming the raw product is $10 \%$ solids. The estimated plant costs are given in Table 2 and the costs of plants using oil and geothermal energy are compared in Table 3.

Table 2. Estimated geothermal drying plant costs

\begin{tabular}{lr}
\hline \multicolumn{1}{c}{ Item } & $\begin{array}{r}\text { Estimated Cost } \\
\text { Twi }\end{array}$ \\
\hline Two production wells & $3,000,000$ \\
Well pumps & $1,000,000$ \\
Slurry pumps & 35,000 \\
Heat exchanger $\left(25,000 \mathrm{ft}^{2}\right)$ & 12,000 \\
& 225,000 \\
Spray nozzles & 50,000 \\
Air blower & 150,000 \\
Product storage facility & 12,000 \\
Solids collection and transport & 17,000 \\
system & 2,500 \\
Cyclone equipment & 12,000 \\
Slurry preheater & 12,000 \\
Air preheater & 23,000 \\
Compressor & 5,000 \\
Slurry conditioner & 125,000 \\
Building & \\
$\quad$ Subtotal & $4,680,500$ \\
Engineering (20\% of total cost) & $1,170,130$ \\
\hline \multicolumn{1}{c}{ Total } & $5,850,630$ \\
\hline
\end{tabular}

The wells represent $68 \%$ of the total cost and engineering represents another $20 \%$. Therefore, the equipment costs are small compared to the "fuel" and engineering costs. It should be noted that the use of two geothermal production wells 
Table 3. Comparative costs of geothermal- and oil-using drying plants

\begin{tabular}{|c|c|c|}
\hline & $\begin{array}{c}\text { Geothermal } \\
\text { (\$) }\end{array}$ & $\begin{array}{l}\text { Oil } \\
(\$)\end{array}$ \\
\hline Initial cost & 5,$850 ; 630$ & $775 ; 625$ \\
\hline Cash investment & 4,$329 ; 465$ & $698 ; 062$ \\
\hline Fuel cost (Year 1) & 24,000 & $742 ; 467$ \\
\hline $\begin{array}{l}\text { Other operating and } \\
\text { maintenance costs } \\
\text { (Year } \eta \text { ) }\end{array}$ & 156,250 & 156,250 \\
\hline
\end{tabular}

and two reinjection wells may be overly conservative; however, optimizing system design should reduce the flow rate and number of wells required.

Comparative Economic Analysis of Geothermal- and Oil-Using :Drying Plants. The cost of plants using geothermal and oil energy were estimated and compared (Table 3 ). To arrive at the estimates given in the table, certain assumptions were necessary. The assumptions common to both forms of energy were:

- Production rate-6250 tons per year

- Operating and maintenance costs other than electricity and fuel- $\$ 25$ per product ton

- Value of waste material before drying-none

- Fuel cost escalation-10\% per annum

- Other escalation-8\% per annum

- Declining balance depreciation-150\% (shift to straight line)

- Plant life-10 years

- Salvage value-none

- Capital replacement-none significant

- Tax credits-used as earned

- Tax bracket-50\%
- Inventory-negligible

- Accounts receivable and payable-turn 12 times per year.

Assumptions made for plants using geothermal energy were:

- Capital costs $-\$ 5,850 ; 630(20 \%$ of capital costs expensed as intangibles)

- Investment tax credit $-20 \%$ average

- Depletion allowance-offsets lease payments :on a cash basis.

- Electrical energy demand-100 kW at 40-mill rate.

Assumptions made for plants using oil were:

- Capital cost for boiler- $\$ 200,000$ (based on $130^{\circ} \mathrm{C}$ process steam)

- Total capital cost $-\$ 775,625$

- Fuel cost-\$33.81 per barrel (Grade 2 fuel oil)

- Investment tax credit-10\%.

A comparative economic analysis (Table 4) examined the economic factors involved in establishing and operating drying plants using geothermal and oil energy as the heat source. Analysis results are, of course, dependent on the dried product value and on the individual company's required rate of return on investment, which greatly affects the choice between the two energy sources.

As the table shows, a product value of less than $\$ 175 /$ ton provides little, if any, incentive to opt for geothermal. The more capital intensive geothermal option requires a higher first cost, which must be weighed against alternative return options.

The geothermal option provides a $16 \%$ return on the incremental investment at a product value of $\$ 175, \$ 200$, and $\$ 500$ per ton. If a company requires a return of less than $16 \%$, the company would be bypassing an attractive investment if it did not invest the additional funds in geothermal. If, however, a $17 \%$ or larger return is required, alternative options may provide the needed return. 
Table 4. Comparative economic analysis of geothermal- and oil-using drying plants

\begin{tabular}{|c|c|c|c|c|c|c|c|c|c|c|c|c|}
\hline & \multicolumn{12}{|c|}{ Dried Product Value } \\
\hline & \multicolumn{2}{|c|}{$\$ 100 /$ ton } & \multicolumn{2}{|c|}{$\$ 125 /$ ton } & \multicolumn{2}{|c|}{$\$ 150 /$ ton } & \multicolumn{2}{|c|}{$\$ 175 /$ ton } & \multicolumn{2}{|c|}{$\$ 200 /$ ton } & \multicolumn{2}{|c|}{$\$ 500 /$ ton } \\
\hline & Geothermal & Oil & Geothermal & Oil & Geothermal & Oil & Geothermal & Oil & Geothermal & Oil & Geothermal & Oil \\
\hline Payback, years ${ }^{a}$ & $10+$ & $b$ & $10+$ & $b$ & $10+$ & $b$ & $9+$ & $10+$ & $8+$ & $4+$ & $2+$ & $<1$ \\
\hline $\begin{array}{l}\text { Internal rate } \\
\text { of return, \% }\end{array}$ & 5.20 & $b$ & 9.02 & $b$ & 12.44 & $b$ & 15.58 & 12.57 & 18.51 & 31.01 & 46.28 & 167.9 \\
\hline $\begin{array}{l}\text { Incremental rate } \\
\text { of return, } \% \mathrm{C}\end{array}$ & NA & $b$ & NA & $b$ & NA & $b$ & 16.05 & NA & 16.05 & NA & 16.05 & NA \\
\hline
\end{tabular}

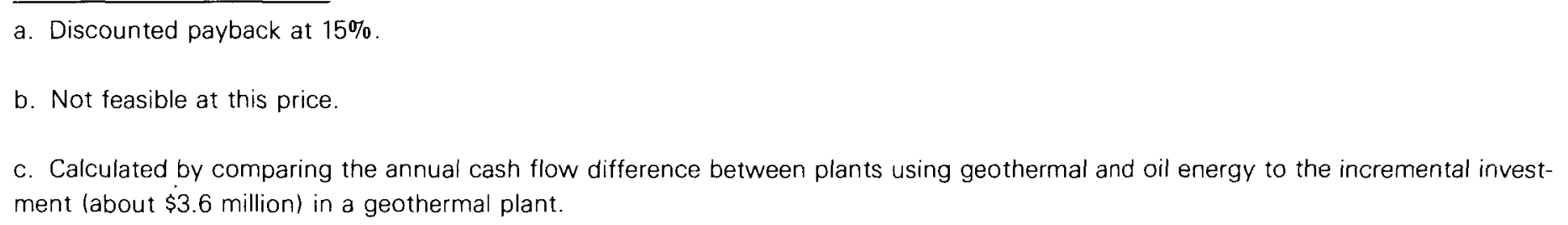

a. Discounted payback at $15 \%$.

b. Not feasible at this price.

c. Calculated by comparing the annual cash flow difference between plants using geothermal and oil energy to the incremental investment (about $\$ 3.6$ million) in a geothermal plant. 


\section{CONCLUSIONS}

The gas-fluidized bed dryer is an effective way of drying a slurry-like raw product to a very low moisture content. The product exits the dryer in granular form or in a powder-like form called fines, and is conducive to pneumatic transport. Although the drying procedure is the same for different slurries, each finished product has its own particle size characteristics. The particle size is also dependent on the operating conditions of the dryer.

Product uniformity is dependent on the quality of atomization achieved by the nozzle. This is the most critical aspect of the design and will require considerable study for scaled-up designs.

Tube bundle efficiency and compactness is also a very important consideration for future designs. An efficient tube bundle reduces both initial capital costs and fluidizing air requirements. Minimizing fluidizing air requirements is important in reducing the required size of the blower and reducing the horsepower required to drive it. Also, less energy would be required to heat the air.

Thermocouples located throughout the fluidized bed are needed to supply the temperature information required to control the dryer. The bed is isothermal in operation under normal conditions, and thermocouples warn of any deviations to allow corrective action.
Clogs and particle agglomeration are usually caused by poor atomization of slurry or by the introduction of too much slurry to the bed, causing bed temperatures to drop below the $15^{\circ} \mathrm{C}$ superheat required to prevent agglomeration. When these two conditions are controlled properly, dryer operation is trouble-free.

The bed-side heat transfer coefficient occurring at the heat exchange tube surface is a strong function of fluidizing air velocity. Maximum heat transfer coefficients of $160 \mathrm{~W} / \mathrm{m}^{2} \cdot \mathrm{K}$ were observed during testing. The velocity at which the maximum occurs depends on the material being dried.

The economics for a commercial-scale geothermal dryer can be appealing. The payback period for the relatively high initial cash investment in a 6-MW(t) drying plant depends largely on the dried product values.

A large scale, gas-fluidized-bed geothermal dryer appears to be feasible. Further scale-up work is needed on atomizing nozzle choice and operation before final, commercial size plants are designed to ensure a trouble-free process. A properly designed fluidized-bed dryer can turn some of industry's waste products into valuable, saleable products. 


\section{REFERENCES}

1. A. Williams-Gardner, Industrial Drying, Cleveland: Chemical Rubber Company, 1971.

2. J. F. Davidson and D. Harrison, Fluidization, London and New York: Academic Press, 1971, pp. 569-597.

3. B. P. Brown, E. S. Grimmett, J. A. Buckham, Devlopment of a Fluidized Bed Calcination Process for Aluminum Nitrate Wastes in a Two-Foot-Square Pilot Plant Calciner, IDO-14586, IDO Office of Technical Services, U.S. Department of Commerce, June 20, 1962, pp. 24, 40.

4. E. S. Grimmett, "Kinetics of Particle Growth in the Fluidized Bed Calcination Process," A.I.Ch.E. Journal, 10, 5, 1964, pp. 717-722.

5. R. B. Bird, W. E. Stewart, E. N. Lightfoot, Transport Phenomena, New York: John Wiley and Sons, Inc., p. 288.

6. V. Zakkay and G. Miller, "Heat Exchanger Designs for Coal-Fired Fluidized Beds," Proceedings of the 13th Intersociety Energy Conversion Engineering Conference, Society of Engineers, SAE/P-78/75, pp. 635-641.

7. J. C. Chen, "Heat Transfer to Tubes in Fluidized Beds," ASME 76-HT-75.

8. D. Kunii and O. Levenspiel, Fluidization Engineering, New York: John Wiley and Sons, Inc., 1969, p. 3.

9. E. S. Grimmett, A. F. Fanous, C. A. Allen, "Advance in Liquid- Fluidized-Bed Heat Exchanger Development," ASME 77-HT-66. 